\title{
THE ATTORNEY-GENERAL AND ALIENS: UNLIMITED DISCRETION AND THE RIGHT TO FAIR TREATMENT*
}

Congress may exclude or deport aliens for any reason it deems proper. ${ }^{1}$ The courts, however, have long held that the deportation of aliens must conform to the procedural requirements of due process of law. ${ }^{2}$ In recent years, there has been an effort to make these requirements a more genuine

* U.S. ex rel. Kaloudis v. Shaughnessy, 180 F.2d 489 (2d Cir. 1950).

1. The Constitution makes no express provision for the control of immigration. Its only reference to aliens is the grant of power to Congress "to establish a uniform rule of naturalization." U.S. CoNST. ART. I, § 8. Nevertheless, the congressional control of immigration is firmly established. The power to exclude aliens is derived from the power to control foreign commerce, Head Money Cases, 112 U.S. 580 (1884), and from the powers "inherent in sovereignty." Ekiu v. United States, 142 U.S. 651, 659 (1892). The power to deport is regarded as a corollary of the power to exclude as well as a power incident to sovereignty. See, Fong Yue Ting v. United States, 149 U.S. 698 (1S93). See, Alexander, Rights of Aliens Under the Federal Constitution 28 (1931); Klainer, Deportation of Aliens, 15 B.U.L. REv. 663, 666 (1935); Oppenheimer, The Constitutional Rights of Aliens, 1 BILl of Rights REv. 100 (1941); Note, 4 WIs. L. REv. 217 (1927). The view that congressional power to deport is plenary has been subjected to vigorous attack from the beginning. See Justices Field and Brewer dissenting in Fong Yue Ting v. United States, supra at 737, 746; Justice Murphy concurring in Bridges v. Wixon, 326 U.S. 135, 161 (1945); Konvitz, Alien and Asiatic in Aimerican Law c. 2 (1946); Note, 44 Col. L. Rev. 736, 749 (1944).

For the history of immigration legislation, see Bernard, AMerican Immigration Policy (1950); Kansas, U.S. IMMrgaration, Exclusion and Deportation (1948). A systematic summary of the basic provisions of the law can be found in Reitzel, The Immigration Laws of the United States-An Outline, 32 VA. L. REv. 1099 (1946). For the general status of the alien in American law, see, Alexander, supra; Konvitz, supra; Gibson, AliENs AND THE LAW (1940); Legis., 83 U. OF PA. L. Rev. 74 (1935).

2. " $[t]$ his court has never held . . that administrative officers . . may disregard the fundamental principles that inhere in due process of law." Japanese Immigrant Case, 189 U.S. 86, 100 (1903). See Bilokumsky v. Tod, 263 U.S. 149, 157 (1923). The alien is also entitled to due process protection when he seeks the discretionary relief of voluntary departure or suspension of deportation. U.S. ex rel. Giacalone v. Miller, 86 F. Supp. 655 (S.D. N.Y. 1949). But, the due process protection afforded the alien in deportation proceedings is less than that received by persons charged with crimes. See, Zakonaite v. Wolf, 226 U.S. 272 (1912). See also, ALEXANDER, op. cit. supra note 1, at 35. For discussion of the scope of the due process protection, see, generally, CLARK, DEPORTATION of ALIENS FROM The U.S. To EURope (1931); King, Deportation-Suggestions to Atrorneys (American Civil Liberties Union 1936); OPPENHEIMER, REPORT ON THE ENFORCENENT OF THE DEPORTATION LAWS OF THE U.S. (National Commission on Law Observance \& Enforcement 1931); Van Vleck, The Administrative Control of Aliens (1932).

Deportation is protected by a broader scope of due process than that enjoyed by exclusion. See United States v. Ju Toy, 198 U.S. 253 (1905) (judicial determination of citizenship denied person seeking admittance); Ng Fung Ho v. White, 259 U.S. 276 (1922) (judicial determination of citizenship granted person held for deportation). See, Note, 31 CoL. L. REv. 1013 (1931). The theory is that the alien who is stopped at the border has not yet fully become subject to American jurisdiction, and thus to the full protection of the Constitution. See United States v. Ju Toy, supra. 
guarantee of fairness to the alien. ${ }^{3}$ One reason has been the growing recognition of the penal character of deportation decrees. ${ }^{4}$ Another has been the fear that uncontrolled administration of the immigration laws might unduly. harass aliens who hold unpopular political beliefs. ${ }^{5}$

Prior to 1940, the law required automatic expulsion of all aliens who were found to have entered the United States improperly, or to have overstayed permits to remain in the country. ${ }^{6}$ Deportation on one of these technical

3. See, Kessler v. Strecker, 307 U.S. 22 (1939) (statute interpreted in such a way as to prevent deportation of alien); Bridges v. Wixon, 326 U.S. 135 (1945). See also, Note, 48 YALE L.J. 111 (1938). For an insight into the basis of this tendency toward greater fairness, see CAHn, The Sense of Injustice 30-32 (1949). Progress in the administration of the laws is noted in King, Treatment of Aliens in Two Wars, 5 LAw. Gund REv. 208 (1945). See note 28 infra. On the other hand, any final assessment of progress must allow for recent tendencies toward administrative arbitrariness. See, U.S. ex rel. Knauff v. Shaughnessy, 338 U.S. 537 (1950) (Attorney-General refused to reveal grounds for excluding alien war bride from admission).

4. Deportation "may result in loss . . of all that makes life worth living." $\mathrm{Ng}$ Fung Ho v. White, 259 U.S. 276, 284 (1922). See also, U.S. ex rel. Klonis v. Davis, 13 F.2d 630 (2d Cir. 1926); Fong Haw Tan v. Phelan, 333 U.S. 6, 10 (1948). The deportation proceeding, while technically not criminal, "smacks of criminal procedure." McGovney, Deportation of Aliens, 18 Iowa L. REv. 187, 188 (1932). See also, Landis, Deportation and Expulsion of Aliens in 5 ENcyc. Soc. Scr. 95 (1931). For a strong argument that deportation should be treated as a criminal proceeding with all criminal protections, See Konvirz, op. cit. supra note 1, ch. 2.

5. Much of the history of the deportation laws could be written in terms of an effort to rid the country of political radicals. Every major addition to the law has broadened the political grounds for deportation. See KANSAS, op. cit. supra note 1, at 206-26. The administration of the law has been marked by the vigor of the Immigration Service in securing political deportations. Landis, op. cit. supra note 4, at 97. The "Palmer Red Raids" following the first world war are well known. That story is well told in Post, ThE Deportation Delirium (1923). See also, Chafee, Free Speech in the United States ch. V (1941). For a vivid description of the methods used in the administration of the laws during this period, see Colyer v. Skeffington, 265 Fed. 17 (D.C. Mass. 1920). The emphasis in the administration of the law upon deporting alien radicals has not entirely disappeared. See the testimony of Attorney-General Tom Clark in the Hearings before the Subcommiltee on Immigration of the House Judiciary Committee on H.R. 2933, 80th Cong., 1st Sess. 132 (1946). See also, Roberts, Investigative Work of the Service, 8 Inar. \& Nat. Serv. Mon. Rev. 66 (1950). The charge has of ten been made that the Immigration Service has tended to measure its success in terms of the number of successful deportations. See Kane, The Challenge of the Wickersham Deportations Report, 23 J. CRIMr. L. \& CRIMInology 575, 581 (1932); OPPENHEIMER, op. cit. supra note 2, at 49 ("the primary interest is to deport as many aliens as possible"). See in this connection the testimony of Edward Shaughnessy, Hearings, sttpra at 39,41 .

6. 43 STAT. 162 (1924), \& U.S.C. \$ 214 (1946); 39 STAT. 889 (1917), 8 U.S.C. $\S 155 a$ (1946). This also applied to alien merchants left in the United States at the termination of commercial treaties. 43 STAT. 154 (1924), 8 U.S.C. $\$ 203$ (1946). See Kansas, op. cit. supra note 1, at 42-3. These "technical" reasons for deportation are distinguished by the Immigration Service from deportations of criminals, moral undesirables, narcotic violators and political undesirables. Several methods were formerly used by the Service to alleviate the harshness of deporting aliens solely on technical grounds. OPPENHEnMER, REPORT ON THE Enforcement of the Deportation Laws 101 (1931). The most common device was delay 
grounds was often ordered many years after the alien had gained entrance to the country. ${ }^{7}$ Frequently, the alien had sunk deep roots in the community. Nevertheless, the law made deportation mandatory even when he possessed unimpeachable moral character and had a dependent family which would suffer as a result of his removal. The harshness of deportation under these circumstances occasioned persistent demands for humane reform. ${ }^{8}$

To remedy the situation, Congress granted the Attorney-General his present power to suspend deportation orders. ${ }^{9}$ This power is limited in such a way that only aliens who would be desirable residents can qualify for the relief. Aliens who are deportable as subversives, narcotics violators, criminals, prostitutes, or procurers are ineligible. ${ }^{10}$ For any alien to qualify, he

in issuing the final deportation order. See testimony of Commissioner MacCormack in Hearings before Senate Committee on Immigration on S. 2969, 74th Cong., 2d Sess. 194 (1936). This relief was, of course, only temporary and such aliens werè eventually deported.

7. The Immigration Act of 1917 contains a 3 year statute of limitation for deportations on grounds of improper entry. However, the courts have interpreted the provisions of the Immigration Act of 1924 to supersede this limitation. If an illegal entry is made after July 1,1924 , the alien can now be deported at any time. E.g., U.S. ex rel. Bhagat Singh v. McGrath, 104 F.2d 122 (9th Cir. 1939).

8. This agitation began in earnest after the publication of three exhaustive studies of the enforcement of the immigration laws: VAN VLECK, op. cit. supra note 2; CLARK, op. cit. supra note 2; Oppenheimer, RePORT ON THE ENFORCEMENT OF THE DePORTATION LAWS OF THE U.S. (1931). All of these criticized the harshness of the law and recommended that discretionary power to suspend deportations in hardship cases be granted. The Department of Labor, which then administered the immigration laws, favored such reform. MExo. of Commissioner of Imi. \& Natur. to Senate and House Committees on Imm. Relatrve to Certain Proposed Changes in the Law (1934). Most of the recommendations were embodied in the Kerr-Coolidge Bill which was first introduced in 1936. H.R. 8163, S. 2969, 74th Cong., 2d Sess. (1936). See Hearings before Senate Committee on Immigration on S. 2969 , 74th Cong., 2d Sess. (1936). Though this bill was not adopted, it occasioned widespread public interest which eventually produced action by Congress. For discussions of the Kerr-Coolidge Bill, see Oppenheimer, Recent Developments in the Deportation Process, 36 Mich. L. REv. 355 (1938); Puttkamer, Legislation Affecting the Deportation of Aliens, 3 U. of CHr. L. Rev. 229 (1936). See also, Adamic, Aliens and Alien Baiters, 173 Harpers 1 (Nov. 1936).

9. 54 StaT. 671 (1940), 8 U.S.C. $\$ 155 \mathrm{c}$ (1946). Suspension has been granted to 32,358 aliens during the operation of the law. This is an average of 3,236 suspensions a year. Communication to YaLE LAw Journal from Raymond Farrell, Assistant Commissioner of Immigration \& Naturalization, dated Nov. 27, 1950, in Yale Law Library. The statute originally provided that all suspensions for more than six months were to be referred to Congress. The deportation order was cancelled if Congress took no action. See MEMo. of CoMMIssioner, supra note 8. In the first seven years of the law's operation, 19,000 cases were submitted to Congress. None of these was rejected. In fact, Congress gave the cases little attention. The Immigration Service, therefore, favored legislation providing for the elimination of the provision requiring submission to Congress. See H.R. 2933, 80th Cong., 1st Sess. (1947). But control by Congress was strengthened, not relaxed. Under the present law, a suspension of more than six months will not be allowed unless approved by affirmative Congressional action. 62 Stat. 1206 (1948), 8 U.S.C. $\$ 155$ c (Supp. 1950). See SEN. REP. No. 1204,80 th Cong., 2 d Sess. (1948). For a recent proposal favoring a return to the original statutory scheme, see BERNARD, op. cit. supra note 1, at 296.

10. 54 Stat. 671 (1940), 8 U.S.C. $\$ 155$ d (1946). See 8 Code Fed. Regs. $\$ 150.10 \mathrm{~b}$ 
must prove good moral character for the five years preceding his application for suspension. ${ }^{11} \mathrm{He}$ must not be ineligible for naturalization. ${ }^{12}$ It must also be established that deportation would result in a serious economic detriment to his family. ${ }^{13}$

Congressional discussion of the law granting the Attorney-General the power to suspend deportation orders indicates that most applications for discretionary relief were expected to be granted. ${ }^{14}$ Vesting this authority in the Attorney-General was intended to alleviate the harshness of the earlier statutory provisions. Harshness persists, however, where the AttorneyGeneral fails to give adequate consideration to the alien's case for suspension.

The courts have so far been unresponsive to the plight of aliens who allege unfair treatment by the Attorney-General. Some flatly hold that the statute confers absolute and unreviewable discretion. ${ }^{15}$ Others, in what appears

(1949). The efforts of the Immigration Service to expand discretionary power to these cases, provided the alien has lived in the U.S. for at least ten years, have not been successful. See H.R. 2933, 80th Cong., 1st Sess. (1947), and Testimony of Edward Shaughnessy, Hearings, supra note 5. See also BERNARD, op. cit. supra note 1, at 295.

11. 54 STAT. 671 (1940), 8 U.S.C. $\$ 155 \mathrm{c}(1946)$.

12. 54 StAT. 671 (1940), 8 U.S.C. $\$ 155 \mathrm{c}$ (1946). This provision was amended in 1948 to allow relief for persons ineligible for naturalization "by reason of race." 62 STAT. 1206 (1948), 8 U.S.C. $\$ 155 \mathrm{c}$ (Supp. 1950). The amendment was primarily designed to aid eligible Japanese aliens. See Hearings, supra note 5.

13. 54 STAT. 671 (1940), 8 U.S.C. $\$ 155 \mathrm{c}$ (1946). A recent amendment permits the Attorney-General to suspend deportation in cases of aliens who have resided in the U.S. for seven years. A showing of economic detriment to the alien's family is not necessary in these cases. 62 Stat. 1206 (1948), 8 U.S.C. $\$ 155$ c (Supp. 1950).

14. Although the Attorney-General's suspension power is discretionary, Congress did not rely on a narrow exercise of discretion to limit the number of suspensions. Instead, Congress so drafted the statute as to prevent any undesirables from remaining in the country as a result of the operation of the statute. Thus, Congress refused to adopt the proposal of the Immigration Service which would have permitted the Attorney-General to suspend the orders of all deportables. Congress instead diligently formulated eligibility requirements which would bar undesirable aliens. "[t]he benefits . . . shall not be extended to aliens who are deportable on grounds which may be generally described as those grounds which indicate that such aliens are likely to be undesirable residents." CoNf. REP. ON H.R. 5138, 76th Cong. 3d Sess. (1940). The deliberate confinement of the power to cases which involve desirable aliens strongly suggests that in those cases, the Congress assumed that the Attorney-General would ordinarily suspend deportation. The debate in Congress was not thorough. See, 86 CoNG. REc. 9029-36 (1940).

15. See, e.g. Sleddens v. Shaughnessy, 177 F.2d 363 (2nd Cir. 1949); U.S. ex rel. Zabadlija v. Garfinkel, 77 F. Supp. 751 (W.D. Pa. 1948). The most extreme statement of this view is that of Judge Jerome Frank to the effect that the statute "confers discretionary unreviewable power." U.S. ex rel. Walther v. Dist. Director, 175 F.2d 693 (2d Cir. 1949). But, Judge Frank has apparently retreated, for he now holds that the court "can compel correction of an abuse of discretion." Mastrapasqua v. Shaughnessy, 180 F.2d 999 (2d Cir. 1950).

The Attorney-General has the power to allow technical deportables with good moral character to depart voluntarily in lieu of deportation. 54 STAT. 671 (1940), 8 U.S.C. $\$ 155 \mathrm{c}$ (1946). For instances of this discretion being regarded as absolute and unreviewable, see, e.g. U.S. ex rel. Bartsch v. Watkins, 175 F.2d 245 (2d Cir. 1949); U.S. ex rel. Salvetti v. Reimer, 103 F.2d 777 (2d Cir. 1939); U.S. ex rel. Von Kleczkowski v. Watkins, 71 F. Supp. 429 (S.D. N.Y. 1947). 
to be the prevailing attitude, grant a very limited review of the discretion. ${ }^{16}$ Under this position, the court will uphold the stated ground for denial of relief by the Attorney-General if it could conceivably be relevant. However, unfair treatment can be easily disguised by an ostensibly reasonable ground of denial. Therefore, the more liberal view of the courts may give an alien little more protection than he would enjoy in the total absence of review.

U.S. ex rel. Kaloudis $v$. Shaughnessy 17 illustrates the meagre protection afforded aliens by the courts. Kaloudis, an alien seaman, was found deportable for overstaying his permit to remain in the United States. Although Kaloudis was found to qualify for the suspension of deportation relief, ${ }^{18}$ his application was denied because he had once belonged to an organization listed by the Attorney-General as subversive. ${ }^{19}$ This decision was made despite the evidence that his membership was innocent and non-political. ${ }^{20}$ The ruling also ignored the fact that the membership was terminated before the Attorney-General's list was compiled ${ }^{21}$ and at a time when the organiza-

16. See, e.g. U.S. ex rel. Weddeke v. Watkins, 166 F.2d 369, 373 (2d Cir. 1948), cert. denied, 333 U.S. 876 (1948); Kavadias v. Cross, 82 F. Supp. 716 (N.D. Ind. 1948), reversed on other grounds, 177 F.2d. 497 (7th Cir. 1949); Mastrapasqua v. Shaughnessy, 180 F.2d 999 (2d Cir. 1950).

For instances of a similar limited review asserted over the Attorney-General's discretion to grant voluntary departure, see, e.g., U.S. ex rel. Giacalone v. Miller, 86 F. Supp. 655 (S.D. N.Y. 1949); U.S. ex rel. Engelbert v. Watkins, 84 F. Supp. 409 (S.D. N.Y. 1946). Cf. U.S. ex rel. U.S. Lines v. Watkins, 170 F.2d 998 (2d Cir. 1948).

17. 180 F.2d 489 (2d Cir. 1950).

18. In establishing his qualifications for the relief, the alien is entitled to the same due process protections that he receives in the determination of his deportability. See 8 CODE FED. REGS. $\$ \S 150.6(\mathrm{~g})(\mathrm{c})(\mathrm{h}), 150.7(\mathrm{c})(1949)$.

19. Kaloudis had once been a member of the International Workers Order. This organization was declared subversive by the Attorney-General pursuant to Exec. Order No. 9835, 12 FED. REG. 1935 (1947) which authorized loyalty checks for all federal employees. Under existing decisions on the subject, it was not given an opportunity to challenge that classification. See Joint Anti-Fascist Refugee Comm. v. Clark, 177 F.2d 79 (D.C. Cir. 1949); International Workers Order v. McGrath, 182 F.2d 368 (D.C. Cir. 1950), cert. granted, 19 U.S.L. WEEK 3096 (1950). See also, Note, Designation of Organization as Subversive by Attorney-General: A Cause of Action, 48 CoL. L. Rev. 1050 (1948).

The list of subversive organizations was designed for the specific purpose of aiding in the determination of loyalty of federal employees. No mention is made in the executive order authorizing the use of the list for other purposes. In the administration of the loyalty program, membership in one of the listed organizations does not in itself establish disloyalty. See letter of Seth Richardson, Chairman of Loyalty Review Board, Transcript of Record, p. 17-18, Kaloudis v. Shaughnessy, 180 F.2d 489 (2d Cir. 1950). Thus, in using Kaloudis' membership in the I.W.O. as sole evidence of disqualification, the AttorneyGeneral was acting in a manner contrary to the established Loyalty Board procedure in cases involving the loyalty of government employees.

20. Kaloudis apparently joined the I.W.O. in 1945 in order to take advantage of its generous insurance and hospitalization benefits. Brieffor Relator, p. 4, Kaloudis v. Shaughnessy, $180 \mathrm{~F} .2 \mathrm{~d} 489$ (2d Cir. 1950). He was a member for a year and a half until he joined the Blue Cross hospitalization plan. He attended three meetings of the I.W.O. during his membership and his participation was limited to listening to what was said. Ibid.

21. Ibid. 
tion was not regarded as a suspicious group by the Immigration Service. ${ }^{22}$ In court, Kaloudis alleged that the Attorney-General abused his discretion in denying the application. This was rejected by the District Court which disclaimed any review power over the discretion. The Court of Appeals for the Second Circuit took the view that a limited review is available where the ground of denial is, on its face, unreasonable. ${ }^{23}$ However, it upheld the discretion in this case because it felt that membership in the proscribed organization might conceivably indicate disloyalty in some cases. In so doing, it ignored any extenuating circumstances which might have established the loyalty of the relator. ${ }^{24}$

The refusal of the court to hold the Attorney-General accountable for the exercise of his discretion, practically restores the automatic expulsion of the old law. It may result in unwarranted hardship on the alien and his family. Discretion which is practically unreviewed deprives the alien of the benefits Congress intended to grant and leaves him without relief from unfair treatment. ${ }^{25}$

22. See, Matter of L-, 56107/933, 1 Ima. \& Nax. Serv. Dec. 450 (1943) (membership in the I.W.O. does not prejudice alien's receiving discretionary preexamination benefit). Until the Kaloudis case, the Immigration Service had not formally modified its attitude toward the I.W.O. See also, Stasiukevich v. Nicolls, 168 F.2d 474 (1st Cir. 1948) (membership in I.W.O. cannot be the sole basis of denial of naturalization).

23. Judge Learned Hand held that the suspension "is a matter of grace, over which courts have no review . . . unless it affirmatively appears that the denial has been activated by considerations that Congress could not have intended to make relevant." U.S. ex rel. Kaloudis v. Shaughnessy, $180 \mathrm{~F} .2 \mathrm{~d} 489,491$ (2d Cir. 1950). Judge Hand suggested as examples of unreasonable considerations a denial on the ground that the alien attended "too many baseball games or had bad table manners." Id. at 490. The circuit court's approach to the problem is explained in the statement that the Attorney-General's authority is exercised as a matter of grace, analogous to the pardoning power of the President. Id. at 491. But this analogy overlooks the consistent refusal of Congress to make the AttorneyGeneral's authority a general "pardoning" power as requested by the Immigration Service. See note 14 supra. This refusal suggests that the eligible alien has a much stronger claim for relief than mere grace.

24. The Kalouldis case should be contrasted with the case of Matter of $\mathrm{K}$ - , A5361313, 2 Imar. \& NAT. SERv. Dec. 838 (1947). There suspension was granted to an alien whose loyalty was seriously questioned due to his activities in the German-American Bund. It was felt that the harshness which would be imposed upon the alien's family outweighed these considerations of loyalty.

25. Much of the movement to reform the administration of the immigration laws was an effort to remove opportunities for the exercise of arbitrary power. See OPPENHEIMER, Report on the ENforcement of the Deportation Laws of the UntTed States c. III (1931); VAN VLECK, op. cit. supra note 2, at 247-51. An example of the results which follow from judicial refusal to curb arbitrary discretion is seen in U.S. ex rel. Ickowicz v. Day, 18 F.2d 963 (2d Cir. 1927). Though agreeing that the alien's case was "most deserving and pathetic," the court nevertheless felt constrained only to appeal to the Attorney-General's sense of justice for correction of the abuse. The court insisted that it was powerless to do more.

The Subversive Activities Control Act of 1950 inposes additional harshness on deportable aliens. If deportation of the alien proves impracticable, the Attorney-General is 
Harshness also results where, as in the Kaloudis case, political criteria are used in the decision. This puts an unnecessary additional loyalty hurdle before the alien when he applies for suspension. If there is substantial evidence of disloyalty, the alien can be deported on those grounds alone. ${ }^{26}$ Thus, ample protection is already afforded against those aliens who present a real threat to the security of the country. ${ }^{27}$

Moreover, denying an alien's claim for suspension on loyalty grounds tends to undermine the protection that due process grants aliens deportable for subversive activity. Recent cases have firmly established the necessity of an exceedingly high degree of proof in order to secure deportation on grounds of subversion. ${ }^{28}$ By shifting the deportation charge from subversive activity to the more technical and less serious charge of overstaying a permit, the Attorney-General can secure deportation without proving that an alien is actually subversive. He need only establish the technical grounds for

now given the power to keep the alien in custody until deportation can be effected. Pub. L. No. 831,81 st Cong., 2d Sess. tit. 1, $\$ 23$ (Sept. 22, 1950).

26. The law requires deportation of aliens who, by reason of personal belief or organizational affiliation, advocate either opposition to all organized government or forcible overthrow of the U.S. Government. See 40 Stat. 1012 (1918), 41 Stat. 1008 (1920), 54 Stat. $673(1940), \&$ U.S.C. $\$ 137$ (1946). For instances of deportations of radicals under these provisions, see Lopez v. Howe, 259 Fed. 401 (2d Cir. 1919); U.S. ex rel. Vajtauer v. Commissioner, 273 U.S. 103 (1927). See also, Note, 48 YaLE L.J. 111 (1938). Section 137 has now been replaced by the more stringent provisions of the Subversive Activities Control Act of 1950. Pub. L. No. 831, 81st Cong., 2d Sess. tit. I $\$ 22$ (Sept. 22, 1950). As a result, the Attorney-General must now deport, in addition to aliens already deportable, the following:

(1) Members or affiliates of the Communist Party; of its subsidiaries; or of any organizations which are its direct predecessors or successors.

(2) Members or affiliates of any totalitarian party.

(3) Advocates of the "economic, international and governmental doctrines of world communism" or affiliates of organizations which advocate those doctrines.

(4) Members of any "communist-front" organizations required to register under the Act unless the aliens can demonstrate their ignorance of the communist character of the organization.

27. Further protection against disloyal aliens might conceivably be introduced when the alien seeks to establish his eligibility for suspension of deportation. If there is serious question concerning his loyalty, the alien might be held to be lacking in the "good moral character" required by the statute. However, such a procedure, in invoking political criteria for moral character, would be subject to the same objections which are advanced against the use of political criteria in denying suspension.

28. The requirements of due process of law were originally held to be satisfied if the deportation order was supported by "some evidence." Vajtauer v. Commissioner, 273 U.S. 103 (1927). However, as a result of Bridges v. Wixon, 326 U.S. 135 (1945), due process now requires that the order be supported by substantial evidence See, Davis, Nonrerierrable Administrative Action, 96 U. of PA. L. Rev. 749, 791 (1948). The Administrative Procedures Act of 1946 réquires that agency action be supported by "substantial evidence." 60 STAT. 243,5 U.S.C. $\$ 1009$ e (1946). Presumably, these provisions now apply to the Immigration Service. Wong Yang Sung v. McGrath, 339 U.S. 33 (1950). A similarly high degree of proof is required to denaturalize a naturalized citizen. See, Schneiderman v. United States, 320 U.S. 118 (1942). See, also, Note, Recent Trends in Denaturalization in the United States and Abroad, 44 CoL. L. REv. 736 (1944). 
deportation and then deny any requests for suspension. Unless this discretion is subjected to effective review, a mildly suspicious alien may be deported with almost no proof of disloyalty while subversive aliens are given the maximum protection of the law.

The courts should assume enough review power over the exercise of discretion by the Attorney-General to guarantee that claims for suspension are treated fairly and with proper consideration. ${ }^{29}$ The manner in which the courts review the discretionary authority to grant bail in deportation cases suggests a possible approach. ${ }^{30}$ In bail cases, the courts have laid down standards to serve as guides for the Attorney-General in the exercise of his authority. ${ }^{31}$ The discretion will not be upheld if the alien shows that the decision does not conform to these standards. ${ }^{32}$ This provides some assurance to the alien that his request for bail will be carefully considered. Similar guides could be formulated to direct the Attorney-General in granting suspension of deportation orders. The major criterion should be that the

29. Habeas corpus is the traditional method of securing review of deportation orders. Gordon, Writ of Habeas Corpus in Deportation Proceedings, 3 ImM. \& NAT. SERv. MoN. Rev. 218 (1945). However, habeas has been vigorously criticized as an ineffectual and cumbersome method of review. See Orlow, Habeas Corpus in Immigration Cases, 10 OHIO Sr. L.J. 319 (1949). If the judicial review provisions of the Administrative Procedures Act apply to deportation proceedings, more expeditious means of review will be available. See Kristenson v. McGrath, 179 F.2d 796 (D.C. Cir. 1949), aff'd, 19 U.S.L. WeEK 4057 (U.S. Dec. 11 1950) (review obtained through declaratory judgement). See, also, Note, The Impact of the Federal Admin. Procedures Act on Deportation Proceedings, 49 CoL. L. Rev. 73 (1949). The major barrier to applying the Act to suspension proceedings is the provision which denies application "where agency action is by law committed to agency discretion." 60 STAT. 243, 5 U.S.C. $\$ 1009$ (1946). However, this apparently will not prevent the courts from asserting review over discretionary authority when they so desire. The Act provides that agency action found to be "an abuse of discretion" be set aside. For a full discussion of the manner in which courts are left to decide the scope of review over discretion, see Davis, supra note 28 , at 791 .

30. The Attorney-General has the power to release an alien on bail pending the final disposal of the case. 39 STAT. 890 (1917), \& U.S.C. $\$ 156$ (1946). \& CODE FED. RIGG. $\$ 150.5$ (1949). The statutory language authorizing this power is as broad as the language conferring discretionary power to suspend deportation orders. Yet the courts have asserted considerable review power over the Attorney-General's exercise of the power. E.g. U.S. $e x$ rel. Potash v. Dist. Dir., 169 F.2d 747 (2d Cir. 1948); U.S. ex rel. Pirinsky v. Shaughnessy, 177 F.2d 708 (2d Cir. 1949). Cf. U.S. ex rel. Bauer v. McGrath, 87 F. Supp. 698 (S.D. N.Y. 1949). See, also, Note, Detention and Bail in Deportation Proceedings, 38 CaL.IF. L. Rev. 326 (1950). The courts do not hold that the Attorney-General must grant the alien's request for bail. U.S. ex rel. Zapp v. Dist. Dir., 120 F.2d 762 (2d Cir. 1941). But they do hold that the alien is entitled to a fair consideration and disposal of his request for bail. The extent to which the courts will go in order to insure fair treatment and consideration for the alien is suggested by the Pirinsky case, supra, where a bond of $\$ 25,000$ was declared excessive.

31. In U.S. ex rel. Potash v. Dist. Dir., supra note 31, at 751, Judge A. Hand listed the following factors upon which the discretion should depend: (1) the probability of the alien being found deportable, (2) the seriousness of the charge against the alien, (3) the danger to the public safety of the alien's presence within the community, and (4) the alien's availabi!ity for subséquent proceedings if given bail release.

32. Ibid. See also, U.S. ex rel. Doyle v. Dist. Dir., 169 F.2d 753 (2d Cir. 1948), 